\title{
Fintech Financing Utilization Model in Developing Small and Medium Enterprises (Case Study of UMKM T-shirts in Bandung City)
}

\author{
Deni Hamdani ${ }^{1}$, Santi Damayanti² \\ Accountant Department, Sekolah Tinggi Ilmu Ekonomi Indonesia Membangun Bandung \\ \{*deni.hamdani@inaba.ac.id\}
}

\begin{abstract}
This research aims to find out how many UMKM already know and utilize fintech financing, the obstacles faced, and develop a model of fintech financing utilization for UMKM business development. Explorative descriptive methods were used in this study, with primary and secondary data types, while sampling was conducted based on purposive sampling method. The results showed that the utilization of fintech financing in UMKM T-Shirt Suci is not optimal because there are still constraints, namely as many as $37.5 \%$ of UMKM entrepreneurs of T-shirt are not yet familiar with fintech financing, $38.13 \%$ do not master technology and $15.63 \%$ fear risk; there is also great potential to optimize the utilization of fintech financing in order to develop businesses, namely a high desire of $84.4 \%$ to acquire knowledge and skills about fintech financing. The important role of the government as regulator, facilitator and catalyst as well as the role of universities as human resources providers that have the capacity and capability of science and skills become important to solve problems through UMKM training and mentoring programs. The model compiled is an overview of the problem/constraints of UMKM Kaos Suci in accessing fintech financing by involving the role of the government and universities, so that existing constraints can be resolved properly and the development of UMKM businesses through access to fintech financing can be successful and effective.
\end{abstract}

Keywords: Financial Technology, Small and Medium Enterprises (UMKM)

\section{Introduction}

In relation to development in the economic sector, especially in realizing economic independence and increasing employment and business opportunities, the UKM development and strengthening program is one of the leading national and regional programs, because UKM are economic actors who are actually able to support the national and regional economies, the number of UKM is very large and has a wide distribution, and the UKM business sector is engaged in all fields / business sectors, but on the other hand for its development UKM are still faced with various problems that need to be facilitated and mediated by the Government, such as the difficulty of UKM in obtaining access to capital in the form of credit, or financing from financial institutions caused by limited guarantees to facilitate access to capital so that it can benefit the community and the regional economy.

Financial technology is considered appropriate for UMKM development if it is tailored to the needs, cost and benefits. Financial technology will help all forms of financial access in UMKM, as well as build business communion through optimization of IFR as a complement 
to information needs. The utilization will help the classic issue of UMKM related to capital financing and marketing, which is supported by Financial Services Authority Regulation No. 77/POJK.01/2016. Utilization of information technology will accelerate the analysis of financial performance on financial statements presented for decision making [1]. Basically, optimization of fintech using IFR will increase the value of MORE UMKM in the eyes of its stakeholders. The problem of capital financing can cause a setback to the existence of UMKM in the current global competition. The condition indicates that the contribution of UMKM is not in line with the existence of growth due to low capital financing [2].

The classic problem around UMKM financing and business development is still a crucial issue. According to references [3] and [4] states that, the government recorded in 2014 out of a total of 56.4 million UMKM in Indonesia, only 30\% of UMKM were able to access financing. Of these percentages, $76.1 \%$ obtained financing from banks and $23.9 \%$ accessed from nonbanks, including cooperatives. The data shows that $60 \%-70 \%$ of all UMKM do not have access to financing. In 2017 , the total accessible financing was only 14.35 million accounts [5]. To boost economic growth through UMKM and creative industries, the government emphasizes several pillars, including: People, Industry, Technology, Resources, Institutions, and Financial Intermediary [6]. Business Concern that is widely developed in Indonesia today, related to industry in the utilization of technology, including such innovations can also be developed in the UMKM sector [ 7]. In the pillars of creative industry development and UMKM, as one of the industries developed by the government and society, UMKM need to build technology utilization in the current digital era.

In response to this, financial technology is an innovation that is considered to increase the market share of UMKM as a step in addressing problems related to capital financing, preparation of financial statements, payments and marketing, as well as financial transactions and financial literacy. Fintech globally is growing rapidly and rapidly in various sectors, ranging from star up payments, financial planning, retail investment, financing, remitting, financial research, and others. Technology Acceptance Model (TAM) Theory states that the use of technology will give a positive reaction to its users. The theory is in line with research [10] that a business that has competitiveness is a type of business that uses technology as part of its business.

The development of financial technology lately is quite massive and continues to grow, including financial technology in financing. The development of financial technology, especially financing, provides various ease of requirements and application of borrowing to debtors. The government through the Financial Services Authority (OJK) continues to encourage the growth of the financial technology peer to peer lending industry or fintech lending to increase financial inclusion. Fintech lending will primarily be directed to expand access to capital of Small and Medium Enterprises (UMKM). This condition is expected to make it easier to develop UMKM. However, the presence of financial technology, especially fintech financing is not immediately and can easily be utilized by UMKM. This is reflected in the low level of UMKM utilizing business financing sources from this financial technology. In 2018 , only 30 percent of small and medium enterprises (UKM) have taken advantage of online loans for productive business needs throughout Indonesia. Therefore, it is necessary to review or research the problem and then create a model of financing utilization through Fintech that can accelerate the development of UMKM.

Based on references and research results, it appears that UMKM are strategically positioned because they contribute significantly to GDP, and are able to absorb a very large workforce. Fintech is present massively and quickly, but cannot be utilized optimally by 
UMKM, therefore there needs to be a model of utilization of Fintech Financing that can accelerate the growth of UMKM.

\section{Methodology}

The selection of this method is based on the purpose of research that is exploratory and describes phenomena (problems) systematically factual and accurate about the model of utilization of financial technology to develop UMKM engaged in the screen printing industry.

\subsection{Types and Data Sources}

The types of data used are primary and secondary data. The data was obtained from the results of questionnaires submitted to respondents (UMKM) of sacred T-shirt centers in Bandung, the results of interviews with UMKM, the results of interviews of financial technology experts, and experts (observers) of UMKM related to the utilization of Fintech financing. While the secondary data collected comes from literature that supports the research of both journals, reports and other forms of publication.

\subsection{Sampling Techniques}

Sampling is done based on purposive sampling method, which is sampling technique with certain considerations. This technique is defined as a sampling process by determining in advance the number of samples to be taken, then the selection of samples is carried out based on certain objectives by not deviating from the characteristics of the specified sample [12]. The types of data used are primary and secondary data. The data was obtained from the results of questionnaires submitted to respondents (UMKM) of sacred T-shirt centers in Bandung, the results of interviews with UMKM, the results of interviews of financial technology experts, and UMKM experts (observers) related to the utilization of Fintech financing. While the secondary data collected comes from literature that supports the research of both journals, reports and other forms of publication.

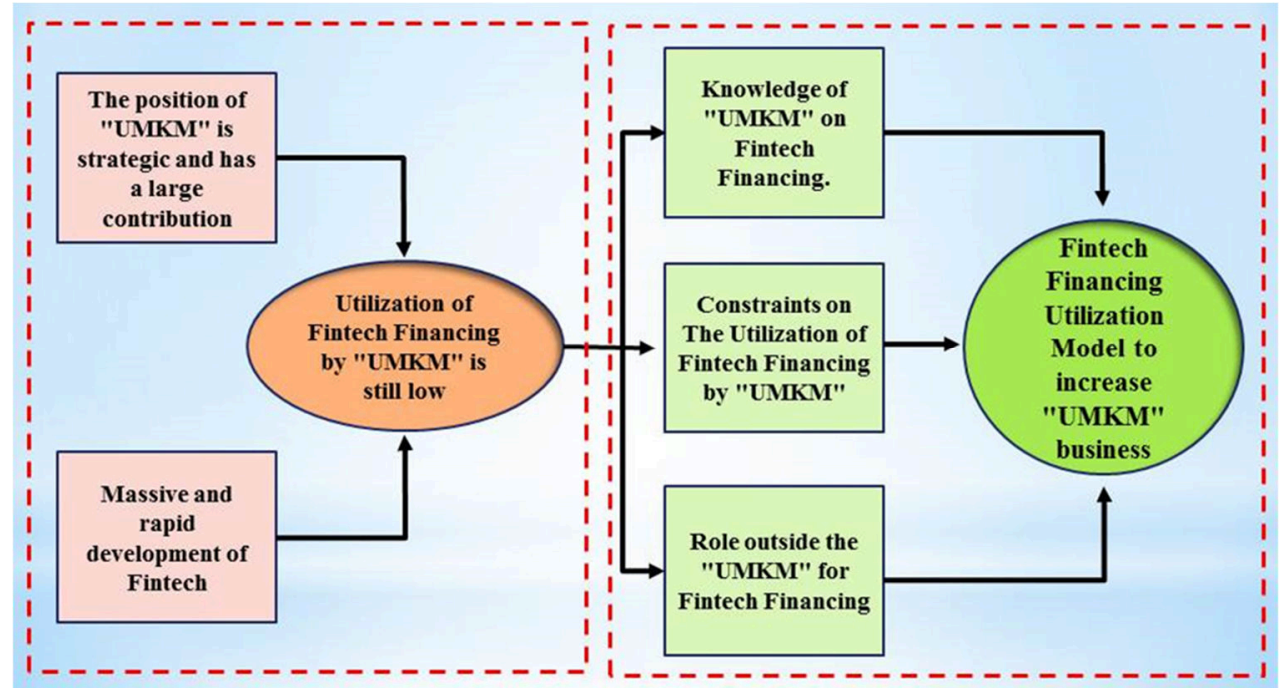

Fig 1. Research Framework 


\section{Result and Discussion}

Financial technology (fintech) is one of the methods of financial services that began to be popular in today's digital era. One part of fintech that develops in Indonesia is fintech financing including in the UMKM sector. The government and the public hope that financing can encourage an increase in the number of people who have access to financial services more effectively and efficiently. Most UMKM entrepreneurs are Sacred T-shirts (62.5\%) know fintech financing but only $43.75 \%$ are new to utilizing this fintech financing. This means that there are still quite a lot of sacred T- shirt entrepreneurs who already know but have not utilized this form of financing. This also means that there is still considerable potential for entrepreneurs to use this source of financing, of course with its various advantages.

In the majority that as many as $65.6 \%$ of respondents want to know more about fintech financing, and the remaining $34.4 \%$ do not want to know. This condition becomes one of the basic capital to introduce fintech financing to respondents. With high curiosity, it will encourage entrepreneurs to try to take advantage of the form of fintech financing. Respondents who do not want to know, need to be properly educated and This is one of the challenges for stakeholders in efforts to increase fintech financing in improving the development of UMKM businesses.

\subsection{Graduate Employability}

There is a great deal of understanding and concepts relevant to graduate employability. According to Hinchliffe and Jolly (2011), the concept that graduates possess unique qualities that also decide their academic position or degree has been widely accepted. For Hillage \& Pollard (1998), graduate employability is the expertise, skills, and qualities that graduates have to demonstrate in higher education. While other concepts likewise distinguish between graduates and non-graduates based on skill sets and characteristics that influence the chances of successful graduate employment (Yorke 2006; Boden and Nedeva 2010).

Graduate employability is indicated when students are trained for fields in which there is a strong need, and the skills and experience of graduates are well-matched with employers' needs in the workplace. According to Knight \& Yorke (2004), four large interlinked components affect employability. These elements are collectively part of the highly skilled communication practices, time- management, actualization, problem solving and personal development, and thorough understanding focused on discipline-based information skills. Bagshow (1997) gave a complex perspective on employability that is not limited to the link between the emerging graduate and the job market and the ownership of the knowledge and competencies to prevail in the working environment (Hedley, 2003).

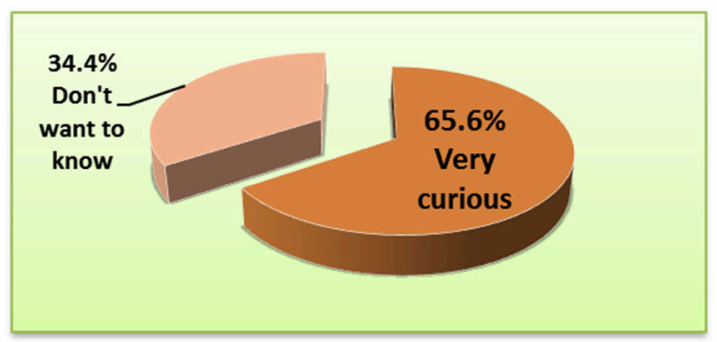

Fig 2. Respondents' Response to Know Fintech Financing 
Another interesting thing is that as a large number, $84.4 \%$ of respondents felt the need to conduct fintech training. In other words, almost as many respondents want to know and want to get training on fintech utilization. This condition is also the potential to provide more knowledge as well as skills in obtaining financing through fintech, so that fintech financing can be optimized as a source of business financing UMKM.

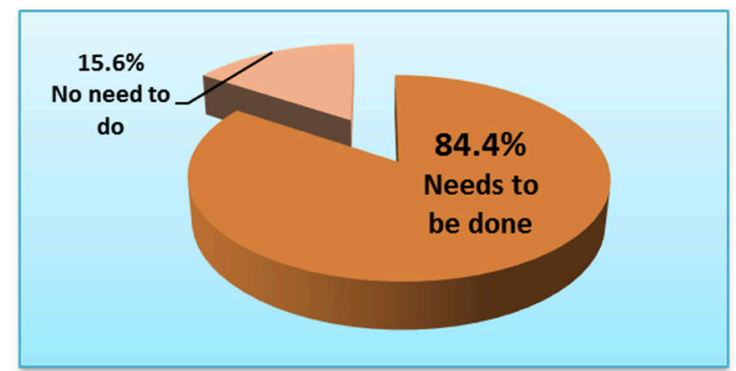

Fig 3. Fintech Utilization Training needs to be conducted

According to them the advantages of fintech financing is a quick disbursement process, easy return process, cheap interest fees, etc. As for UMKM that have not used fintech as a source of financing due to constraints, technology rulers, requirements that have not been met, even fear of risk. These advantages and constraints can be used as the basis for other institutions that are interested and have competencies to play a role in optimizing the utilization of excess and reducing the constraints of the existence of fintech UMKM development. Institution that need to play a role in optimizing fintech for UMKM development include the Government, Local Government, Universities, and Fintech Owners themselves.

\subsection{Government role.}

The role of the government in developing UMKM includes 3 things, namely as facilitators, regulators and catalysts. As a government facilitator, it can be done through funding programs (business credit referrals), human resource development programs, and market development programs. These programs have been done quite a lot by the government among $\mathrm{T}$ - shirt entrepreneurs, but the specifics of fintech financing have not been carried out, in accordance with the opinion of respondents. Therefore, there needs to be a special program related to the role of the government for the utilization of fintech financing in increasing UMKM businesses. The role of the government as a regulator, is a function as a control holder of business and business activities carried out by UMKM. Government products containing regulating provisions include policies on micro, small and medium enterprises. The role of the government can be said to be real if the output produced in this case UMKM actors can feel a positive impact with the existence of the established rules. In terms of research developed in this research, the output of the government's role in UMKM development lies in the direction and ease of government regulation on the requirements for obtaining fintech financing, such as business licenses and other permits related to the requirements that must be met by UMKM to obtain funding from fintech.

Another thing is the role of catalysts, namely the role of persuasive government that invites people to entrepreneurship [14], the role is needed to provide stimulus to the community, especially those who are constrained by funding for entrepreneurship with sources of financing from fintech. Until now the role of the government related to optimizing the 
utilization of fintech financing for UMKM T-Shirt Suci is still considered minimal. Therefore, the presence of the government as regulators, facilitators and catalysts in the framework of fintech financing is expected, namely through the provision of direction and ease of requirements to obtain access to capital from fintech.

\subsection{The Role of Universities}

The role of universities in increasing the utilization of fintech financing is carried out through technical assistance or with the term UMKM mentoring pattern. The pattern of UMKM assistance by some circles is seen as providing tangible and positive results. UMKM that obtain financing are expected to get managerial guidance day to day. In addition to preventing misallocation of funds resulting in bad credit, this mentoring pattern also aims to help UKM in creating institutional systems (capacity building) in order to create added value for their businesses in the future. The role of universities is needed to fill consultants in mentoring programs by optimizing the potential of lecturers and/or students they have.

Universities act as agents of expertise for UKM, because they have Human Resources (lecturers and students) who understand and have knowledge that can solve UMKM problems in improving and developing their businesses, especially those that are constrained by access to capital. Student involvement is first equipped with soft skills about team work and organization, science and practical skills to solve problems faced by UMKM, especially regarding fintech financing, so that when released or assigned, then they are ready to help solve UMKM problems, also need to be accompanied by supervisors who are experts in their fields. In this way, the knowledge and skills of students and lecturers will be more felt, and UMKM problems can also be solved.

\subsection{Fintech Financing Utilization Model for UMKM Business Development}

The utilization of fintech financing by UMKM of Kaos Suci is considered not optimal, because there are still those who have not utilized fintech financing of $56.25 \%$, because they do not know fintech (37.5\%), do not master technology (38.13\%), fear of risk (15.63\%). Behind the reason for the unoptimal utilization of fintech financing there is great potential to optimize the utilization of fintech financing to develop UMKM businesses, namely the desire to obtain knowledge and ability (training) on fintech is quite high (84.4\%). Therefore, it is necessary to increase the utilization of fintech financing for UMKM. The involvement of the government and universities has a significant role in tackling obstacles and potentials, so that the development of UMKM T-shirt through fintech financing can be successful. In the diagram, the model of fintech financing utilization to develop UMKM Kaos Suci is described as shown in the picture below.

The survey results of the constraints of UMKM entrepreneurs in obtaining funding from fintech financing include 2 large parts, namely mastery of technology and fulfillment of requirements. For the annularity of technology can be solved through technology mastery training carried out by universities that have competencies and capacities in the field of technology, while the constraints of requirements can be resolved by the government as a facilitator through coaching programs and ease of fulfillment of requirements in obtaining business licenses and other permits. Coaching, training, facilitation will be more successful if followed up with sustainable university assistance in running the business wheel, so that UMKM can be more developed which is initiated by increasing the ability to obtain increased capital capacity through access to capital through fintech financing. 


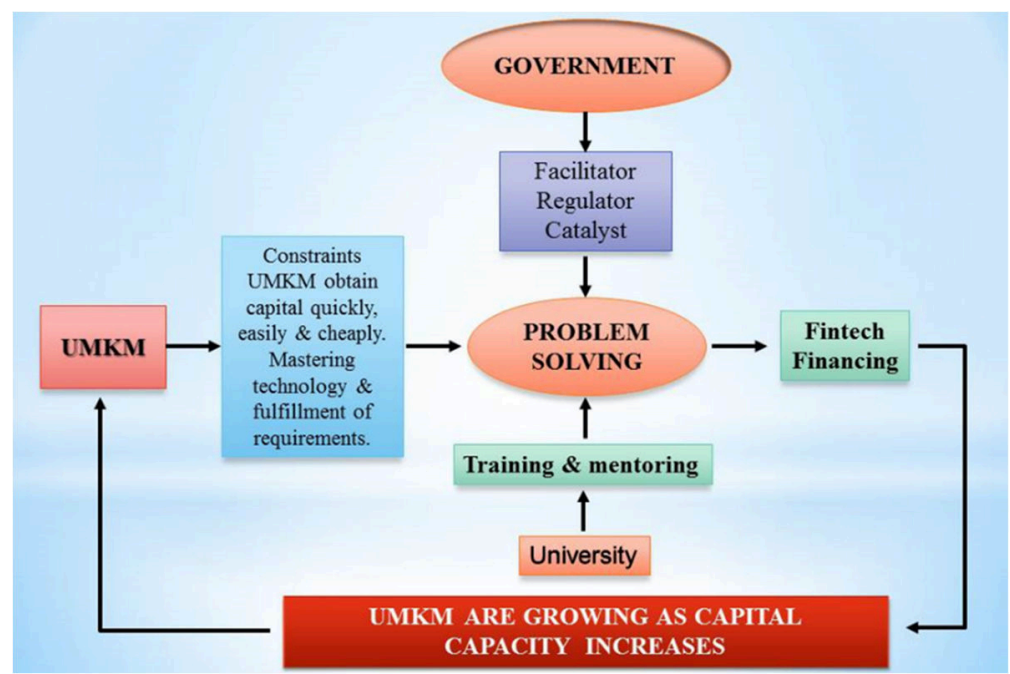

Fig 4. Fintech Financing Utilization Model in Developing UMKM

\section{Conclusion}

Utilization of fintech financing in UMKM T-Shirt is not optimal because there are still constraints. There is great potential to optimize the utilization of fintech financing in developing UMKM businesses, especially in acquiring knowledge and skills about fintech financing. UMKM development through fintech financing requires the role of the government as a regulator, facilitator and catalyst through a low-cost fund referral program, ease of management of permits required in obtaining fintech financing and other stimulus for UMKM business development. The role of universities as a provider of human resources that has the capacity and capability of science and skills to solve problems in UMKM through UMKM training and mentoring programs. Fintech financing utilization model for UMKM business development is a model that illustrates the obstacles faced by UMKM to be able to access fintech financing, therefore the role of governments and universities is very important in solving problems, so that UMKM business development can be successful and effective.

\section{Acknowledgment.}

Our deep gratitude to the Directorate of Research and Community Service Directorate General of Strengthening Research and Development of the Ministry of Research, Technology and Higher Education (KEMENRISTEK DIKTI) who has provided grants for The Research of Beginner Lecturers (PDP), in the hope that this research can provide benefits for all of us. 


\section{References}

[1] Hasyim, N., Hidayah, N. A., \& Latisuro, S.W. (2014). Rancang Bangun Sistem Informasi Koperasi Berbasis Web Pada Koperasi Warga Baru MTSN 17 Jakarta. Jurnal Sistem Informasi, 7(2), 1-10.

[2] Data Kredit UMKM Bank Indonesia (2012-2017) (Diakses 19 Januari 2018), dari www.bi.go.id

[3] Data UMKM Bank Indonesia, (Diakses 16 Februari 2018), dari www.bi.go.id

[4] Data UMKM Ikatan Akuntan Indonesia (2017), (Diakses 10 Januari 2018), dari www.iaiglobal.or.id

[5] Data Koperasi dan UKM (2017). (Diakses 19 Januari 2018), dari www.depkop. go.id/dataumkm

[6] Barus. (2016). Peran Internet dalam Komunikasi Pemasaran Produk UMKM. Jurnal Admnistrasi Bisnis.Vol.12 No.1. Universitas Katholik Parahyangan. Bandung.

[7] Alyas \& Rakib. (2017). Strategi Pengembangan Usaha Mikro, Kecil dan Menengah Dalam Penguatan Ekonomi Kerakyatan (Studi Kasus Pada Usaha Roti Maros Di Kabupaten Maros).Sosiohumaniora.Vol.19,No.2:11 4-120.Sekolah Tinggi Ilmu Ekonomi Yayasan Pendidikan Ujung Pandang- Universitas Negeri Makassar.

[8] Putri \& Agustina. (2017). Peran Mahasiswa Akuntansi Sebagai Pendorong bersaing dalam MEA. Jurnal Akuntansi Universitas Udayana. Vol.18, No.2

[9] Irma Muzdalifa, Inayah Aulia Rahma, Bella Gita Novalia (2018). Peran Fintech dalam Meningkatkan Keuangan Inklusif pada UMKM di Indonesia (Pendekatan Keuangan Syariah). Jurnal Masharif al- Syariah: Jurnal Ekonomi dan Perbankan Syariah Vol. 3, No. 1, 2018 ISSN: 2527 - 6344 (Print) ISSN: 2580 - 5800 (Online)

[10] Almilia, L. S. (2009). Analisa Komparasi Indeks Internet Financial Reporting Pada Website Perusahaan Go Publik Di Indonesia. In Seminar Nasional Aplikasi Teknologi Informasi (SNATI)., ISSN: 1907-5022, 31-32

[11] Aidil Zulkifli, (2019). Fintech Rambah Permodalan Sektor UMKM. Radar Tasikmalaya. Maret

[12] Sugiyono. (2008) Metode Penelitian Kuantitatif, Kualitatif Dan R \& D. Bandung: Alfabeta.

[13] Rifzaldi Nasri. (2013). Pemberdayaan Ukm Melalui Peran Perguruan Tinggi Guna Memperoleh Pembiayaan Syariah. Proceeding Seminar Nasional Isbn: 978- 979-636-147-2 Dan Call For Papers Sancall 2013 Surakarta, 23 Maret 2013

[14] Saharudin, Nazaki, Handrisal, (2018), Peran Pemerintah dalam Pengembangan Usaha Mikro Kecil dan Menengah di KotaTanjungpinang. file://d:/kajian\% 202019/pdp\% 20pa\%20 deni/ peran $\% 20$ pemerintah $\% 20$ dalam $\% 20$ umkm.pdf 